\title{
THE BLUE JAY
}

Published quarterly by the Saskatchewan Natural History Society

Founded in 1942 by Isabel M. Priestly

Authorized as second class mail and for payment of postage in cash

P.O. Department, Ottawa

Vol. XXV, No. 2 JUNE, 1967 Pages 53-104

\section{TABLE OF CONTENTS}

ECOLOGY OF THE GREAT SANDHILLS AND CYPRESS HILLS

PLATEAU, Jan Looman

BIRDS

The Upland Plover and its status in relation to environmental

conditions and situations, past and present, G. J. Mitchell.

Notes on the breeding biology of the Marsh Hawk in Alberta and

Saskatchewan, Spencer G. Sealy

Two banding returns for Golden Eagle and Peregrine Falcon, E. Kuyt 70

Fishing lures, a hazard to sea birds, R. Wayne Campbell ..................... 71

Commensal feeding of gull and Peregrine, Errol Anderson................. 72

Some nest histories of the Black-billed Magpie in southwestern

Alberta, Robert K. Shaw

Black-throated Blue Warbler reaches Belcher Islands, N.W.T.,

Stanley Zazalenchuk

Mountain Chickadee in southwestern Saskatchewan, Steve A. Mann...

Canada Goose nesting record for Battleford, Spencer G. Sealy.

Birds at Inglewood bird sanctuary, Calgary....

PLANTS

Mustards and pinks, Keith F. Best

Are you interested in mushrooms? Connie B. Pratt

NEW BUTTERFLY RECORDS FOR SASKATCHEWAN AND

ALBERTA, Ronald R. Hooper

HISTORY OF THE COUGAR IN SASKATCHEWAN, Thomas White

UNIOR NATURALISTS, edited by Joyce Deutscher

\section{THE BLUE JAY BOOKSHELF}

Wildlife habitat improvement, by Joseph J. Shomon, Byron L.

Ashbrough and Con D. Tolman, reviewed by Margaret Belcher

Plants of Bottineau County, North Dakota, by A. O. Sitevens, reviewed by Elizabeth Cruickshank

The Elk, by John Madson, reviewed by Anthony J. Hruska.....

Do you know? Exploring nature around Prince William Sound, Alaska, by Cecil Lee Shumaker, reviewed by Elizabeth Cruickshank.......

Cypress Hills Plateau-Alberta and Saskatchewan. Part I-Technical papers, edited by R. L. Zell. Part II-Program, geological road logs and maps, edited by Irmgard Weihmann, reviewed by John H. Hudson

Any material printed for the first time in the Blue Jay may be reproduced vithout permission. Credit lines will be appreciated. 